\title{
miR-3664-5P suppresses the proliferation and metastasis of gastric cancer by attenuating the NF-кB signaling pathway through targeting MTDH
}

\author{
YUWEN JIAO*, HAOJUN YANG ${ }^{*}$, JUN QIAN*, YU GONG, \\ HANYANG LIU, SIYUAN WU, LIANG CAO and LIMING TANG \\ Department of Gastrointestinal Surgery, The Affiliated Changzhou No. 2 People's Hospital \\ of Nanjing Medical University, Changzhou, Jiangsu 213000, P.R. China
}

Received July 13, 2018; Accepted November 16, 2018

DOI: $10.3892 /$ ijo.2019.4680

\begin{abstract}
Gastric cancer (GC) is one of the most common and fatal types of cancers worldwide and the specific mechanism has not been completely elucidated. microRNA (miR)-3664-5P has rarely been studied and the aim of the present study was to assess an association between miR-3664-5P and GC. Differences in miR-3664-5P expression in $100 \mathrm{GC}(0.1846 \pm 0.08276)$ and paired normal tissues $(0.4382 \pm 0.1595)$ were detected using reverse transcription-quantitative polymerase chain reaction assays $(\mathrm{P}<0.001)$. 5-Ethynyl-2-deoxyuridine, Cell Counting Kit-8, transwell and flow cytometry assays were performed in vitro and the results were further verified using a mouse xenotransplantation and a lung metastasis model in vivo. miR-3664-5P was significantly downregulated in GC tissues when compared with normal tissues and positively associated with the prognosis of patients with GC $(\mathrm{P}<0.001)$. Overexpression of miR-3664-5P suppressed and miR-3664-5P knockdown promoted the proliferation and metastasis of $\mathrm{GC}$ cells in vitro and in vivo. Following the application of bioinformatic algorithms and luciferase reporter assays, metadherin (MTDH) was confirmed as the target gene of miR-3664-5P. miR-3664-5P reduced MTDH expression and downregulated the nuclear factor (NF)- $\mathrm{\kappa B}$ signaling pathway. Rescue experiments demonstrated that suppression of MTDH restored the effect of miR-3664-5P inhibitors on GC cell lines. The results suggested that miR-3664-5P suppressed the proliferation and metastasis of GC cells by attenuating the
\end{abstract}

Correspondence to: Professor Liming Tang, Department of Gastrointestinal Surgery, The Affiliated Changzhou No. 2 People's Hospital of Nanjing Medical University, 68 Gehu Middle Road, Changzhou, Jiangsu 213000, P.R. China

E-mail: drtangliming@163.com

${ }^{*}$ Contributed equally

Key words: gastric cancer, microRNA-3664-5P, metadherin, nuclear factor- $\kappa \mathrm{B}$, biomarker
NF- $\mathrm{BB}$ signaling pathway via MTDH targeting. Consequently, miR-3664-5P may have potential to be an independent prognostic factor and biomarker in GC.

\section{Introduction}

Due to the development of modern healthcare and changes in dietary habits, gastric cancer (GC) is the fifth most common lethal neoplasm (1), but it remains the third leading cause of cancer-associated mortalities worldwide, following lung and liver cancer $(1,2)$. Statistically, as an aggressive disease, $~ 950,000$ new cases are diagnosed each year and $>720,000$ cases of mortality have been reported for GC in Europe (3). In China, patients with GC account for $~ 42 \%$ of GC cases worldwide. Despite improvements in surgical and oncological treatments, the 5-year survival rate for patients with GC remains low, reported as $<30 \%$ in developed countries (2). The mechanisms leading to the occurrence and development of $\mathrm{GC}$ remain to be investigated.

MicroRNAs (miRNA/miRs) are short, 22 nucleotides-long, non-coding RNA molecules, that negatively regulate transcription via sequence-specific interactions with the 3'-untranslated regions (UTRs) of target genes $(4,5)$. Various studies have indicated that miRNAs serve a critical role in tumorigenesis and development by targeting different genes (5-9) and many are involved in controlling GC-associated cellular processes, including proliferation, migration, differentiation, apoptosis and cell cycle progression (5,10-13). As comprehensive care strategies for GC are improving, but still remain unsatisfactory $(14,15)$, there is an urgency to determine and understand the molecular mechanisms underlying GC progression. Thus, in the present study, the role miRNA may serve in the development of GC was explored.

miR-3664-5P is a novel miRNA and its function in tumors, particularly GC, remains to be investigated. According to the TargetScan database (mirdb.org/cgi-bin/search. cgi), miR-3664-5P matches with the mRNA sequence of metadherin (MTDH) without mismatch, thus ranking first to target MTDH. MTDH, which is also known as astrocyte elevated gene-1, 3D3 or LYRIC, is a transmembrane protein that is induced in primary human fetal astrocytes infected 
with human immunodeficiency virus (HIV)-1 or treated with recombinant HIV-1 envelope glycoprotein (16). MTDH has been recognized as an oncogene in various cancers, including glioma, melanoma and neuroblastoma, and in carcinomas of the breast, prostate, liver and esophagus, for its significant role in promoting the proliferation, angiogenesis, invasion, metastasis and chemoresistance of cancer cells via activation of the nuclear factor $(\mathrm{NF})-\kappa \mathrm{B}$, phosphoinositide 3-kinase/protein kinase $\mathrm{B}$, mitogen-activated protein kinase and Wnt signaling pathways (17-24). In GC, MTDH was demonstrated to promote progression using a positive feedback Toll-like receptor $4 / \mathrm{NF}-\kappa \mathrm{B}$ signaling-associated mechanism, which is widely recognized to serve a crucial role in inflammation and carcinogenesis $(23,25)$. Therefore, the aim of the present study was to determine the role of miR-3664-5P in GC, and investigated whether its function was associated with targeting $\mathrm{MTDH}$ and regulating the $\mathrm{NF}-\kappa \mathrm{B}$ signaling pathway.

\section{Materials and methods}

Patients and tumor tissues. In the present study, 100 paired fresh GC and adjacent normal tissues were collected from patients with GC (27-87 years old), who underwent resection of GC without local or systemic treatment prior to operation at the Department of Gastrointestinal Surgery in Changzhou No. 2 People's Hospital (Jiangsu, China) between July 2010 and October 2012. All patients, consisting of 71 males and 29 females, were aged between 27 and 87 years old (average age, 61.9 years). Patients provided written informed consent and the experimental procedures were approved by the Ethics Committee of the Nanjing Medical University Affiliated Changzhou No. 2 People's Hospital (approval no. 2010-SR-077.A1). All specimens were confirmed by clinical, radiographic and histological examination for GC. Clinicopathological data such as age and gender, as well as lymph node metastasis status, clinical stage, differentiation, tumor size and $\mathrm{T}$ classification were obtained by reviewing the patients' pathology records. Clinical stage was determined according to the American Joint Committee on Cancer staging criteria (26).

Cell lines. All GC cell lines (BGC823, MGC803, SGC7901, AGS and MKN45) and normal epithelial gastric cells (GES-1) were obtained from Nanjing KeyGen Biotech Co., Ltd. (Nanjing, China). GC cell lines were cultured to $70-80 \%$ confluence for subsequent experiments in RPMI-1640 (Gibco; Thermo Fisher Scientific, Inc., Waltham, MA, USA) with $10 \%$ fetal bovine serum (Gibco; Thermo Fisher Scientific, Inc.) and $80 \mathrm{U} / \mathrm{ml}$ penicillin at $37^{\circ} \mathrm{C}$ in humidified air containing $5 \% \mathrm{CO}_{2}$. To generate higher transfection efficiency and better results in vitro and in vivo, MGC803 and MKN45 cells were chosen to construct miR-3664-5P overexpressionand knockdown-cell lines, respectively, due to the highest miR-3664-5P expression observed in MKN45 cells and the lowest miR-3664-5P expression observed in MGC803 cells.

Reverse transcription-quantitative polymerase chain reaction $(R T-q P C R)$. Total RNA from tissues and cells was isolated using TRIzol reagent (Sigma-Aldrich; Merck KGaA, Darmstadt, Germany) and were reverse transcribed using the
PrimeScript RT Master mix (Takara Biotechnology Co., Ltd., Dalian, China) with the following temperature protocol: $37^{\circ} \mathrm{C}$ for $15 \mathrm{~min}$ and $85^{\circ} \mathrm{C}$ for $5 \mathrm{sec}$, then held at $4^{\circ} \mathrm{C}$. Expression levels of miR-3664-5P and MTDH were determined via qPCR with the SYBR Premix Ex Taq (Takara Biotechnology Co., Ltd.) on the ABI Prism 7900HT (Applied Biosystems; Thermo Fisher Scientific, Inc.) according to the manufacturer's instructions. The thermocycling conditions were as follows: Hot-start DNA polymerase activation at $95^{\circ} \mathrm{C}$ for $10 \mathrm{~min}$, followed by 40 cycles of $95^{\circ} \mathrm{C}$ for $15 \mathrm{sec}$ and $60^{\circ} \mathrm{C}$ for $1 \mathrm{~min}$, and then one cycle of melt curve analysis at $95^{\circ} \mathrm{C}$ for $15 \mathrm{sec}, 60^{\circ} \mathrm{C}$ for $1 \mathrm{~min}$ and $95^{\circ} \mathrm{C}$ for $15 \mathrm{sec}$. Primer sequences for qPCR were as follows: miR-3664-5P, forward, 5'-GCCGAGAACTCTGTC TTCAC-3' and reverse, 5'-CTCAACTGGTGTCGTGGA-3'; MTDH, forward, 5'-AAATGGGCGGACTGTTGAAGT-3' and reverse, 5'-CTGTTTTGCACTGCTTTAGCAT-3'; GAPDH, forward, 5'-GGAGCGAGATCCCTCCAAAAT-3' and reverse, 5'-GGCTGTTGTCATACTTCTCATGG-3'; interleukin (IL-8), forward, 5'-GTGCAGAGGGTTGTG GAGAAG TTT-3' and reverse, 5'-TCACTGGCATCTTCACTGATT CTTG-3'; matrix metalloproteinase 9 (MMP9), forward, 5'-TG TACCGCTATGGTTACACTCG-3' and reverse, 5'-GGCAGG GACAGTTGCTTCT-3'; vascular endothelial growth factor (VEGF), forward, 5'-TGCATTCACATTTGTTGTGC-3' and reverse, 5'-AGACCCTGGTGGACATCTTC-3'. The expression of miR-3664-5P, MTDH, IL-8, MMP9 and VFGF were normalized to GAPDH and the expression levels were calculated using $2^{-\triangle \Delta \mathrm{Cq}}$ methods (27).

Western blot assays. Radioimmunoprecipitation Assay buffer containing phenylmethanesulfonyl fluoride (Beyotime Institute of Biotechnology, Haimen, China) was used to extract proteins from cells and tissues according to the manufacturer's protocol. The protein concentration was determined using a bicinchoninic acid protein assay kit (Beyotime Institute of Biotechnology). Proteins (40 $\mu \mathrm{g})$ were then separated by $10 \%$ SDS-PAGE and transferred onto polyvinylidene fluoride membranes (EMD Millipore, Billerica, MA, USA). Then, the membranes were blocked in 5\% non-fat milk for $2 \mathrm{~h}$ at room temperature and incubated with specific primary antibodies at $4^{\circ} \mathrm{C}$ overnight. Following washing with $0.02 \mathrm{mmol} / 1 \mathrm{TBST}$ ( $0.1 \%$ Tween; $3 \times 10 \mathrm{~min})$, the membranes were then incubated with secondary antibodies (anti-rabbit or anti-mouse) at room temperature for $2 \mathrm{~h}$. The immunoreactive protein bands were visualized using Enhance Chemiluminescence Plus (EMD Millipore) with a bio-imaging system. The primary and secondary antibodies employed in the present study were as follows: MTDH (1:1,000; cat. no. ab45338; Abcam, Cambridge, UK), NF- $\kappa$ B inhibitor $\alpha(\mathrm{I} \kappa \mathrm{B} \alpha ; 1: 1,000$; cat. no. 4814; Cell Signaling Technology, Inc., Danvers, MA, USA), p65 (1:1,000; cat. no. 8242; Cell Signaling Technology, Inc.), phosphorylated (p)-p65 (1:2,000; cat. no. 3033; Cell Signaling Technology, Inc.), GAPDH (1:1,000; cat. no. 5174; Cell Signaling Technology, Inc.), anti-rabbit horseradish peroxidase (HRP)-conjugated secondary antibodies (1:5,000; cat. no. 7074; Cell Signaling Technology, Inc.) and anti-mouse HRP-conjugated secondary antibodies (1:5,000; cat. no. 7076; Cell Signaling Technology, Inc.). ImageJ software 1.47 (National Institutes of Health, Bethesda, MD, USA) was applied to quantify the integrated density of the bands. 
Knockdown and overexpression of miRNA. miR-3664-5P mimics (5'-AACUCUGUCUUCACUCAUGAGU-3') and its negative control (NC) (5'-UUGUACUACACAAAAGUA CUG-3'), and miR-3664-5P inhibitor (Sponge sequence: 5'-ACUCAUGAGUGAAGACAGAGUU-3') and its NC (5'-UU CUCCGAACGUGUCACGUAA-3') were synthesized by Nanjing KeyGen Biotech Co., Ltd. The miRNA mimics $(50 \mathrm{nM})$ or inhibitor $(100 \mathrm{nM})$, and their NCs (50 and $100 \mathrm{nM}$, respectively), were transfected into GC cell lines (4x10 $/$ well) using Lipofectamine ${ }^{\circledR} 3000$ (5 $\mu \mathrm{l} /$ well; Invitrogen; Thermo Fisher Scientific, Inc.). Cells were used for subsequent experiments at $48 \mathrm{~h}$ post-transfection.

Knockdown of MTDH. Small interfering (si)-RNA targeting MTDH (5'-AGCCGUAAUCAACCCUAUAUC-3') and a NC sequence (5'-UUCUCCGAACGUGUCACGUAA-3') were obtained from Shanghai GenePharma Co., Ltd. (Shanghai, China). siRNAs $(50 \mathrm{nM})$ were transfected into cells $\left(4 \times 10^{5} /\right.$ well) in 6-well plates using Lipofectamine ${ }^{\circledR} 3000$ (5 $\mu \mathrm{l}$ /well; Invitrogen; Thermo Fisher Scientific, Inc.). Cells were used for subsequent experiments at $48 \mathrm{~h}$ post-transfection.

Cell viability assay. To determine the effect of miR-3664-5P on the proliferation of GC cells (MKN45 and MGC803), a Cell Counting Kit-8 (CCK-8) kit (Dojindo Molecular Technologies, Inc., Kumamoto, Japan) and a Cell-Light 5-Ethynyl-2'-deoxyuridine (EdU) Apollo567 In vitro kit (Guangzhou RiboBio Co., Ltd., Guangzhou, China) were utilized. For CCK- 8 detection, $2 \times 10^{3}$ cells/well were cultured in 96-well plates, each well containing $100 \mu 1$ RPMI-1640 (Gibco; Thermo Fisher Scientific, Inc.) with $10 \%$ fetal bovine serum (Gibco; Thermo Fisher Scientific, Inc.) and $80 \mathrm{U} / \mathrm{ml}$ penicillin. Following 24, 48, 72 and 96 h, $10 \mu \mathrm{l} \mathrm{CCK-8} \mathrm{assay}$ reagent was added to each well mixed with $90 \mu \mathrm{l}$ serum-free medium. The absorbance was then measured $2 \mathrm{~h}$ later using a microplate reader at $450 \mathrm{~nm}$, with $630 \mathrm{~nm}$ as reference wavelength. For the EdU assay, cells $\left(2 \times 10^{5}\right)$ were seeded into Glass Bottom Cell Culture Dishes (Wuxi Nest Biotechnology, Co., Ltd., Wuxi, China), then the cells were treated according to manufacturer's instructions. Finally, images were captured under a laser confocal scanning microscope (Carl Zeiss AG, Oberkochen, Germany).

Plate colony formation assay. Cells (1,000/well) were cultured in 6-well plates to investigate the effect of miR-3664-5P on the efficiency of colony formation. Following 7 days, each well was washed with PBS three times at room temperature. The cells were then fixed using ethyl alcohol for $30 \mathrm{sec}$ and stained for $20 \mathrm{~min}$ at room temperature using crystal violet dye. Following washing with PBS, colonies ( $\geq 50$ cells/colony) in each well were manually counted and images were captured using a digital camera (Canon DS126211; Canon, Inc., Tokyo, Japan).

Transwell assay. Cell migration and invasion were analyzed in 24-well plates with sterile polycarbonate chambers $(8-\mu \mathrm{m}$ filters; BD Biosciences, Franklin Lakes, NJ, USA) with or without Matrigel coating. Cells $\left(2 \times 10^{4}\right)$ were cultured in $100 \mu \mathrm{l}$ serum-free RPMI-1640 in the upper chamber and $600 \mu \mathrm{l}$ RPMI-1640 plus 10\% fetal bovine serum (Gibco; Thermo
Fisher Scientific, Inc.) in the lower chamber. Following $24 \mathrm{~h}$, the lower chamber was washed twice with PBS and stained with crystal violet dye for $20 \mathrm{~min}$. The chamber was then washed again with PBS three times, and a cotton bud was used to remove cells and medium from the upper chambers. The migrated and invaded cells in the lower chambers were observed under a light microscope (NIKON ECLIPSE TI-SR; Nikon Corporation, Tokyo, Japan; magnification, x200).

Flow cytometry analysis of cell cycle and apoptosis. Cell cycle distribution was determined with a Cell Cycle Assay kit (Vazyme, Piscataway, NJ, USA) according to the manufacturer's instructions. Cells $\left(6 \times 10^{5}\right)$ were cultured in 6-well plates and treated with $50 \mu \mathrm{M} \mathrm{H}_{2} \mathrm{O}_{2}$ for $2 \mathrm{~h}$ at $37^{\circ} \mathrm{C}$ to induce apoptosis and were then analyzed using an Annexin V-fluorescein isothiocyanate/propidium iodide Apoptosis Detection kit (Vazyme). Cell cycle distribution and the levels of apoptosis were analyzed using a flow cytometer equipped with BD FACSDiva Software 6.0 (BD Biosciences).

Animals and subcutaneous tumor growth assays. A total of 20 male BALB/c nude mice (age, 4-8 weeks; 13-15 g) were purchased from the Laboratory Animal Center of Yangzhou University (Yangzhou, China) and kept under specific pathogen-free conditions. All experiments were approved by Animal Ethics Committee of Nanjing Medical University (Nanjing, China). Mice were maintained at room temperature $\left(20-26^{\circ} \mathrm{C}\right)$ with a humidity level of $50-60 \%$ and a 12-h light/dark cycle, and were bred under specific pathogen-free conditions in accordance with the institutional animal care and use committee regulations. Mice received $5 \mathrm{~g}$ food and $100 \mathrm{ml}$ water per $100 \mathrm{~g}$ body weight per day. MGC803 cells $\left(1 \times 10^{7}\right)$ transfected with the miR-3664-5P overexpression lentivirus (left groin) and NC (right groin) were suspended in $100 \mu \mathrm{l}$ PBS and injected subcutaneously into nude mice. The tumor sizes were measured every five days using micrometer calipers, and tumor volumes were calculated as follows: Tumor volume $=\left(\right.$ width $^{2} \mathrm{x}$ length $) / 2$. Following 30 days, the mice were sacrificed by carbon dioxide inhalation (air displacement rate: 20\%/min; Yuyan Instruments Company, Shanghai, China). All animal experiments were performed in compliance with the relevant ethical regulations per an approved Institutional Animal Care and Use Committee protocol, including a tumor size limit of $2.0 \mathrm{~cm}$ in any dimension. The maximum tumor volume observed in the mice was $1.0285 \mathrm{~cm}^{3}\left[\left(1.1^{2} \times 1.7\right) / 2\right]$. The maximum observed combined diameter in the cases where multiple tumors occurred was $1.9 \mathrm{~cm}$.

Lung metastasis model. A single-cell suspension was prepared with cells stably overexpressing miR-3664-5P or NC lentivirus, suspended in $200 \mu \mathrm{l}$ PBS and filtered through a sterile $70-\mu \mathrm{m}$ nylon mesh filter (BD Biosciences). Mice were separately injected with MGC803 cells $\left(5 \times 10^{6}\right)$ with or without miR-3664-5P overexpression via the tail vein to develop peripheral intravascular-implanted models (10 mice/group). Mice were sacrificed 5 weeks later and tumor metastases in the lung were examined. Hematoxylin and eosin staining was used to evaluate the number of tumors in lung tissues. Briefly, lung tissues were fixed in 
A

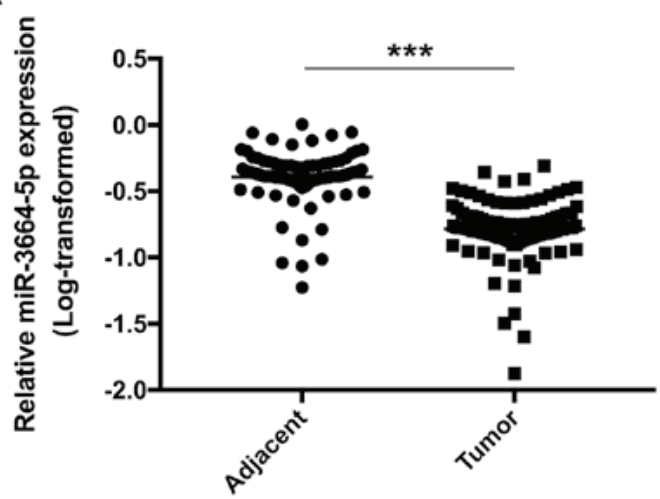

C

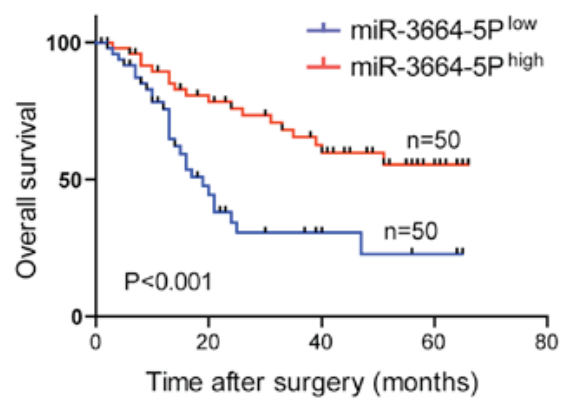

D

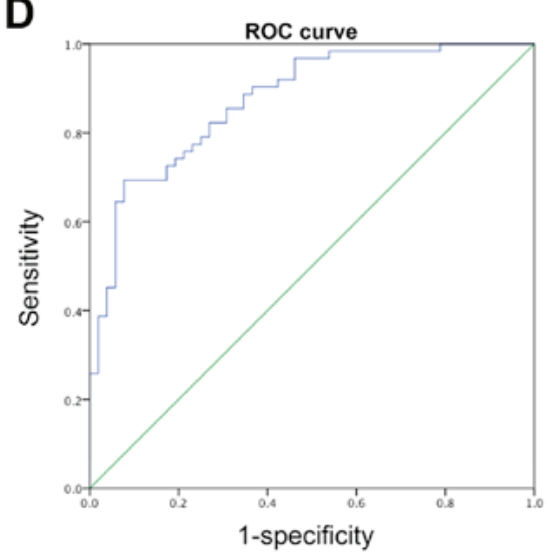

B
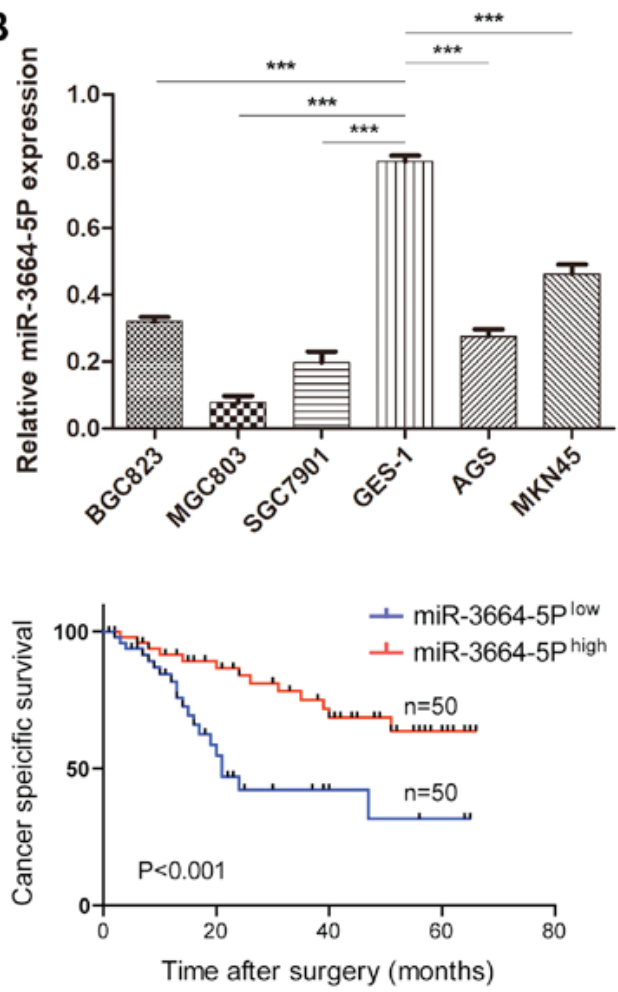

Area under the curve

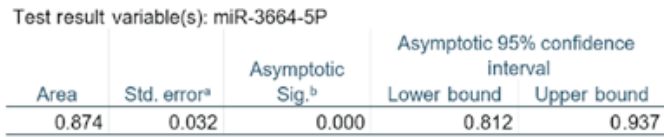

a. Under the nonparametric assumption

b. Null hypothesis: true area $=0.5$

Figure 1. miR-3664-5P is significantly downregulated in GC and associated with favorable prognosis in patients with GC. (A) miR-3664-5P expression in 100 human GC and paired adjacent normal tissues was detected via RT-qPCR. (B) miR-3664-5P expression was downregulated in GC cell lines when compared with the human normal gastric cell line GES-1; miR-3664-5P expression was determined by RT-qPCR with GAPDH as control. (C) Kaplan-Meier analysis indicated that patients with high miR-3664-5P expression $(n=50)$ had a better overall survival and cancer specific survival when compared with the low expression group ( $\mathrm{n}=50$ ). (D) miR-3664-5P expression was detected in preoperatively obtained plasma from patients with GC ( $=60)$ and compared with tumor-free patients $(n=40)$. ROC curve analysis of miR-3664-5P was utilized to detect the diagnostic efficiency of GC. Data are presented as mean \pm standard error of the mean. ${ }^{* * *} \mathrm{P}<0.001$, as indicated. miR, microRNA; GC, gastric cancer; RT-qPCR, reverse transcription-quantitative polymerase chain reaction; ROC, receiver operating characteristic.

$10 \%$ formalin at room temperature for $24 \mathrm{~h}$, dehydrated with different concentrations of alcohol (70,85, 95 and 100\%) and xylene, embedded in paraffin and sliced into $4-\mu \mathrm{m}$ sections Following deparaffinization in xylene and rehydration in different concentrations of alcohol (100, 95, 85 and 70\%) and distilled water, sections were stained with hematoxylin for $5 \mathrm{~min}$ and eosin for $2 \mathrm{~min}$ at room temperature, dehydrated with different concentrations of alcohol $(70,85$, 95 and $100 \%$ ) and xylene, and covered with a coverslip with mounting medium (Sangon Biotech Co., Ltd., Shanghai, China). The sections were viewed and images were captured under a light microscope (NIKON ECLIPSE TI-SR; Nikon Corporation; magnification, x200).
Immunohistochemistry (IHC). For IHC, the UltraSensitive ${ }^{\mathrm{TM}}$ SP (Mouse/Rabbit) IHC kit (Fuzhou Maixin Biotech Co., Ltd., Fuzhou, China) was used with the streptavidin-biotin amplification method. Briefly, human gastric cancer, paired adjacent normal and mice subcutaneous tumor tissues were fixed in $10 \%$ formalin at room temperature for $24 \mathrm{~h}$, dehydrated with different concentrations of alcohol (70, 85, 95 and 100\%) and xylene, embedded in paraffin and sliced into $4-\mu \mathrm{m}$ sections. Following deparaffinization in xylene and rehydration in different concentrations of alcohol (100, 95, 85 and 70\%) and distilled water, sections were blocked with $0.3 \%$ hydrogen peroxide and incubated with $0.03 \mathrm{M}$ citrate buffer $(\mathrm{pH} 6.0$ ) in a pressure cooker at $121^{\circ} \mathrm{C}$. Nonspecific tissue reactions 
Table I. Associations between miR-3664-5P expression and clinicopathological characteristics of patients with GC ( $\mathrm{n}=100$ ).

\begin{tabular}{|c|c|c|c|c|}
\hline \multirow[b]{3}{*}{ Clinicopathological features } & \multirow[b]{3}{*}{ Total n $(n=100)$} & \multicolumn{2}{|c|}{ miR-3664-5P expression } & \multirow[b]{3}{*}{ P-value } \\
\hline & & Low & High & \\
\hline & & No. of patients (\%) & No. of patients (\%) & \\
\hline Sex & & & & 0.826 \\
\hline Male & 71 & $36(72.0)$ & $35(70.0)$ & \\
\hline Female & 29 & $14(28.0)$ & $15(30.0)$ & \\
\hline Age, years & & & & 0.406 \\
\hline$\leq 50$ & 64 & $30(60.0)$ & $34(68.0)$ & \\
\hline$>50$ & 36 & $20(40.0)$ & $16(32.0)$ & \\
\hline Differentiation & & & & $0.016^{\mathrm{a}}$ \\
\hline Well/ moderately & 56 & $22(44.0)$ & $34(68.0)$ & \\
\hline Poor & 44 & $28(56.0)$ & $16(32.0)$ & \\
\hline Clinical stage & & & & 0.069 \\
\hline I-II & 43 & $26(52.0)$ & $17(34.0)$ & \\
\hline III-IV & 57 & $24(48.0)$ & $33(66.0)$ & \\
\hline Tumor size $(\mathrm{cm})$ & & & & $0.016^{\mathrm{a}}$ \\
\hline$\leq 3.5$ & 50 & $19(38.0)$ & $31(52.0)$ & \\
\hline$>3.5$ & 50 & $31(52.0)$ & $19(38.0)$ & \\
\hline Lymph node metastasis & & & & 0.420 \\
\hline No & 44 & $20(40.0)$ & $24(48.0)$ & \\
\hline Yes & 56 & $30(60.0)$ & $26(52.0)$ & \\
\hline $\mathrm{T}$ classification & & & & 0.838 \\
\hline $\mathrm{T}_{1}-\mathrm{T}_{2}$ & 61 & $31(62.0)$ & $30(60.0)$ & \\
\hline $\mathrm{T}_{3}-\mathrm{T}_{4}$ & 39 & $19(38.0)$ & $20(40.0)$ & \\
\hline
\end{tabular}

Data were analyzed by Chi-squared test. ${ }^{\mathrm{P}}<0.05$. miR, microRNA.

were blocked using $10 \%$ bovine serum (Servicebio, Woburn, MA, USA) for $30 \mathrm{~min}$ at room temperature and sections were incubated with the anti-MTDH (LYRIC) primary antibody (1:300; cat. no. ab45338; Abcam) overnight at $4^{\circ} \mathrm{C}$, followed by incubation with horseradish peroxidase-conjugated secondary antibody (1:1,000; polyclonal, cat. no. ab6721; Abcam) for $15 \mathrm{~min}$ for at room temperature. Sections were then visualized using 3,3'-diaminobenzidine solution (Fuzhou Maixin Biotech Co., Ltd.) for $1 \mathrm{~min}$ at room temperature. Following dehydration, transparency and sealing, the sections were viewed and images were captured under a light microscope (NIKON ECLIPSE TI-SR; Nikon Corporation; magnification, x200).

Bioinformatics analysis and Luciferase activity reporter assay. Target genes of miR-3664-5P were predicted using the TargetScan database (www.targetscan.org; release no. 7.2) and miRDB database (www.mirdb.org) by searching for the presence of conserved orthologous 3'-UTRs of humans that matched the seed region of $\mathrm{miR}-2664-5 \mathrm{P}(28,29)$. The luciferase reporter assay was carried out using pDL-reporter vectors (Guangzhou RiboBio Co.) containing the wild-type (WT) or mutant (Mut) MTDH 3'-UTR sequences. Cells (1x105/well) in a 24-well plate were cotransfected with miR-3664-5P mimics/inhibitors or the corresponding controls along with the
WT/Mut MTDH 3'-UTR vectors using Lipofectamine ${ }^{\circledR} 3000$ (1 $\mu \mathrm{l} /$ well; Invitrogen; Thermo Fisher Scientific, Inc.). The luciferase activity was measured using a dual-luciferase assay kit (Beyotime Institute of Biotechnology) according to the manufacturer's instructions at $48 \mathrm{~h}$ post-transfection; luciferase activities were normalized to Renilla luciferase activities as the internal standard of transfection efficiency.

Statistical analysis. Patients were divided into low and high miR-3664-5P expression groups according to the median RT-qPCR results. Correlations between miR-3664-5P expression and various clinicopathological parameters were analyzed by $\chi^{2}$ test. Student's t-test was applied to evaluate the significance between two samples. The expression levels of miR-3664-5P and MTDH in tumor and normal tissues were analyzed via paired $\mathrm{T}$ tests, while the tumor weight as well as the number of metastasis lesions in vivo were analyzed using unpaired $\mathrm{T}$ test. One-way analysis of variance and least-significant difference post hoc tests were used to compare datasets containing multiple groups. The log rank test was employed in the analysis of Kaplan-Meier curves. Clinical characteristics that exhibited significant associations with survival in univariate analyses $(\mathrm{P}<0.05)$ were entered into multivariate analyses, performed using the Cox proportional 
Table II. Univariate and multivariate survival analyses evaluating miR-3664-5P expression influencing overall survival in gastric cancer $(\mathrm{n}=100)$.

\begin{tabular}{|c|c|c|c|c|}
\hline \multirow[b]{2}{*}{ Variables } & \multicolumn{2}{|c|}{ Univariate } & \multicolumn{2}{|c|}{ Multivariate analysis } \\
\hline & $\mathrm{HR}(95 \% \mathrm{CI})$ & P-value & $\mathrm{HR}(95 \% \mathrm{CI})$ & P-value \\
\hline Sex & & 0.427 & & NA \\
\hline Male & 1 & & & \\
\hline Female & $0.770(0.404-1.468)$ & & & \\
\hline Age, years & & 0.389 & & NA \\
\hline$\leq 50$ & 1 & & & \\
\hline$>50$ & $0.753(0.395-1.436)$ & & & \\
\hline Differentiation & & $0.010^{\mathrm{b}}$ & & $0.013^{\mathrm{a}}$ \\
\hline Well/ moderately & 1 & & 1 & \\
\hline Poor & $2.176(1.207-3.923)$ & & $2.201(1.178-4.113)$ & \\
\hline Clinical stage & & 0.188 & & NA \\
\hline I-II & 1 & & & \\
\hline III-IV & $1.501(0.820-2.750)$ & & & \\
\hline Tumor size, $\mathrm{cm}$ & & $0.041^{\mathrm{a}}$ & & 0.170 \\
\hline$\leq 3.5$ & 1 & & 1 & \\
\hline$>3.5$ & $1.867(1.027-3.396)$ & & $1.546(0.829-2.883)$ & \\
\hline Lymph node metastasis & & $0.009^{\mathrm{b}}$ & & $0.003^{b}$ \\
\hline No & 1 & & 1 & \\
\hline Yes & $2.252(1.225-4.139)$ & & $2.601(1.379-4.907)$ & \\
\hline T classification & & 0.372 & & NA \\
\hline $\mathrm{T}_{1}-\mathrm{T}_{2}$ & 1 & & & \\
\hline $\mathrm{T}_{3}-\mathrm{T}_{4}$ & $1.306(0.726-2.350)$ & & & \\
\hline miR-3664-5P expression & & $0.001^{\mathrm{c}}$ & & $0.029^{\mathrm{a}}$ \\
\hline Low & 1 & & 1 & \\
\hline High & $0.360(0.195-0.666)$ & & $0.492(0.260-0.931)$ & \\
\hline
\end{tabular}

All of the results were adjusted using Cox proportional hazards models for differentiation, tumor size, lymph node metastasis and miR-3664-5P expression. ${ }^{\mathrm{a}} \mathrm{P}<0.05$; ${ }^{\mathrm{b}} \mathrm{P}<0.01$; ${ }^{\mathrm{C}} \mathrm{P}<0.001$. NA, not adopted; HR, hazards ratio; CI, confidence interval; miR, microRNA.

hazard model. Receiver operating characteristic (ROC) curve analysis was used to detect the diagnostic efficiency of miR-3664-5P in GC. The area under the curve was calculated, and the optimum sensitivity and specificity were determined using the Youden index. All statistical analyses were conducted with SPSS 17.0 (SPSS, Inc., Chicago, IL, USA) and GraphPad Prism 5 (GraphPad Software, Inc., La Jolla, CA, USA). The results of the in vitro experiments were presented as the mean \pm standard error of the mean from three independent experiments, while data obtained from the in vitro experiments were presented as the mean \pm standard deviation. $\mathrm{P}<0.05$ was considered to indicate a statistically significant difference.

\section{Results}

miR-3664-5P is significantly downregulated in GC tissues and cell lines. To help understand the role of miR-3664-5P in GC, RT-qPCR was performed in $100 \mathrm{GC}$ and adjacent normal tissues, which demonstrated that when compared with the normal tissues, miR-3664-5P expression was significantly downregulated in GC tissues ( $\mathrm{P}<0.001$; Fig. 1A). Similar results were observed in the GC cell lines when compared with the normal gastric epithelial cell line GES-1; miR-3664-5P expression was suppressed in the BGC823, MGC803, SGC7901, AGS and MKN45 GC cell lines ( $\mathrm{P}<0.001$; Fig. 1B).

High levels of miR-3664-5P are associated with favorable prognosis in patients with GC. To further investigate the clinical relevance of miR-3664-5P and its prognostic value in GC, patients were divided into high and low miR-3664-5P expression groups according to the median expression level as determined by RT-qPCR. Expression of miR-3664-5P was correlated with differentiation $(\mathrm{P}=0.016)$ and tumor size $(\mathrm{P}=0.016$; Table I). However, no significant association was identified when comparing sex, age, clinical stage, lymph node metastasis and $\mathrm{T}$ classification. In addition, patients with high miR-3664-5P expression had a higher probability of a better overall $(\mathrm{P}<0.001)$ and cancer-specific prognosis $(\mathrm{P}<0.001)$ compared with the low miR-3664-5P expression group (Fig. 1C). Cox proportional hazards regression 
Table III. Univariate and multivariate survival analyses evaluating miR-3664-5P expression influencing cancer specific survival in gastric cancer $(n=100)$.

\begin{tabular}{|c|c|c|c|c|}
\hline \multirow[b]{2}{*}{ Variables } & \multicolumn{2}{|c|}{ Univariate } & \multicolumn{2}{|c|}{ Multivariate analysis } \\
\hline & $\mathrm{HR}(95 \% \mathrm{CI})$ & P-value & $\mathrm{HR}(95 \% \mathrm{CI})$ & P-value \\
\hline Sex & & 0.880 & & NA \\
\hline Male & 1 & & & \\
\hline Female & $0.945(0.458-1.952)$ & & & \\
\hline Age, years & & 0.362 & & NA \\
\hline$\leq 50$ & 1 & & & \\
\hline$>50$ & $0.700(0.325-1.507)$ & & & \\
\hline Differentiation & & $0.006^{\mathrm{b}}$ & & $0.024^{\mathrm{a}}$ \\
\hline Well/moderately & 1 & & 1 & \\
\hline Poor & $2.625(1.310-5.260)$ & & $2.257(1.114-4.573)$ & \\
\hline Clinical stage & & 0.536 & & NA \\
\hline I-II & 1 & & & \\
\hline III-IV & $1.245(0.622-2.493)$ & & & \\
\hline Tumor size, $\mathrm{cm}$ & & 0.163 & & NA \\
\hline$\leq 3.5$ & 1 & & & \\
\hline$>3.5$ & $1.641(0.818-3.288)$ & & & \\
\hline Lymph node metastasis & & 0.150 & & NA \\
\hline No & 1 & & & \\
\hline Yes & $1.663(0.832-3.326)$ & & & \\
\hline $\mathrm{T}$ classification & & 0.790 & & NA \\
\hline $\mathrm{T}_{1}-\mathrm{T}_{2}$ & 1 & & & \\
\hline $\mathrm{T}_{3}-\mathrm{T}_{4}$ & $1.009(0.550-2.196)$ & & & \\
\hline miR-3664-5P expression & & $0.003^{\mathrm{b}}$ & & $0.010^{\mathrm{b}}$ \\
\hline Low & 1 & & 1 & \\
\hline High & $0.334(0.163-0.686)$ & & $0.380(0.183-0.791)$ & \\
\hline
\end{tabular}

All of the results were adjusted using Cox proportional hazards models for differentiation and miR-3664-5P expression. ${ }^{\mathrm{a}} \mathrm{P}<0.05$; ${ }^{\mathrm{b}} \mathrm{P}<0.01$. NA, not adopted; HR, hazards ratio; CI, confidence interval; miR, microRNA.

analyses suggested that miR-3664-5P expression was an independent prognostic predictor for overall survival [hazard ratio $(\mathrm{HR})=0.492 ; \mathrm{P}=0.029$ ] and cancer specific survival ( $\mathrm{HR}=0.038$; $\mathrm{P}=0.01$; Tables II and III). ROC curve analysis was performed to investigate the effectiveness of miR-3664-5P for GC prediction. Serum samples of GC patients collected prior to resections of GC $(n=60)$ and control serum samples collected from people undergoing physical examinations $(n=40)$ were utilized. The expression of miR-3664-5P in serum was detected by RT-qPCR. The results indicated that miR-3664-5P may be an effective predictor for GC diagnosis with a sensitivity of 0.923 and a specificity of 0.694 (Fig. 1D). These results suggested that miR-3664-5P may serve a critical role in GC development, and serve as a biomarker for GC diagnosis and prognosis.

miR-3664-5P inhibits GC cell proliferation, migration and invasion in vitro. MGC803 and MKN45 cells were chosen to construct miR-3664-5P overexpression- and knockdown-cell lines, respectively, due to their relatively low and high
miR-3664-5P expression. The miR-3664-5P inhibitors and mimics were transfected into MGC803 and MKN45 cells in order to establish miR-3664-5P overexpression and knockdown GC cell lines. The miR-3664-5P overexpression cell line for in vivo experiments was constructed by transfecting a lentivirus-plasmid into MGC803 cells to induce miR-3664-5P overexpression. The transfection efficiency was confirmed by RT-qPCR $(\mathrm{P}<0.001$; Fig. $2 \mathrm{~A})$. It was demonstrated that miR-3664-5P upregulation inhibited GC cell proliferation and migration, and miR-3664-5P downregulation had the reverse effect on CCK8, EdU and plate colony assays $(\mathrm{P}<0.01$; Fig. 2B-D). Flow cytometry assays were performed to evaluate the effects of miR-3664-5P regulation on apoptosis and the cell cycle. The results revealed that miR-3664-5P overexpression in GC cells resulted in significant promotion of apoptosis and cell cycle arrest, whereas miR-3664-5P knockdown significantly suppressed apoptosis and promoted the accumulation of cells in the $\mathrm{S}$ and $\mathrm{G} 2$ stage $(\mathrm{P}<0.05$; Fig. 3A and $\mathrm{B})$. The transwell assay revealed that miR-3664-5P overexpression in decreased and miR-3664-5P inhibition in increased migration and 

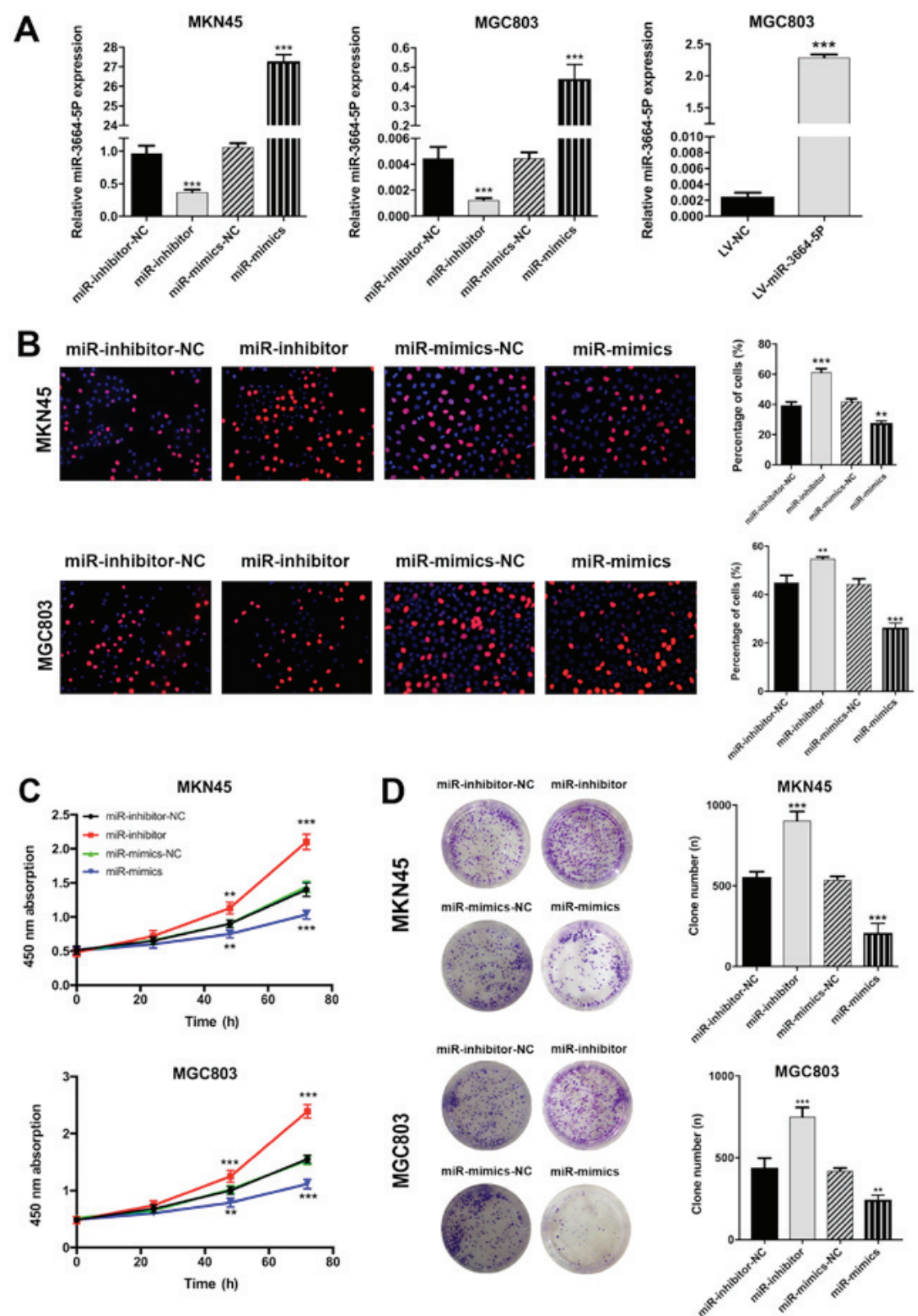

Figure 2. miR-3664-5P inhibits GC cell proliferation in vitro. (A) Following transfection with miR-3664-5P mimics or inhibitors, the expression of miR-3664-5P was significantly upregulated or downregulated, respectively, in the MKN45 and MGC803 cell lines. MGC803 was transfected with miR-3664-5P overexpression lentivirus for in vivo assays. miR-3664-5P levels were determined by reverse transcription-quantitative polymerase chain reaction. (B) EdU, (C) Cell Counting Kit-8 and (D) plate colony assays were performed to detect the viability of GC cell lines (magnification, x200). miR-3664-5P upregulation inhibited and miR-3664-5P downregulation promoted the proliferation of GC cells. Data are presented as the mean \pm standard error of the mean, from three independent experiments. ${ }^{* *} \mathrm{P}<0.01$ and ${ }^{* * *} \mathrm{P}<0.001$ vs. the corresponding NC. NC, negative control; miR-inhibitor-NC, cells transfected with the negative control of the miR-3664-5P inhibitor; miR-inhibitors, cells transfected with miR-3664-5P inhibitors; miR-mimics-NC, cells transfected with the negative control of the miR-3664-5P mimics; miR-mimics, cells transfected with miR-3664-5P mimics; miR, microRNA; GC, gastric cancer; LV, lentivirus.

invasion in the MGC803 and MKN45 cell lines $(\mathrm{P}<0.001$; Fig. 4A and B). Taken together, the above results demonstrated that miR-3664-5P inhibited GC cell proliferation, migration and invasion in vitro.

miR-3664-5P acts as an inhibitor of tumor growth in vivo. A xenotransplantation model was established in order to gain better understanding of the role of miR-3664-5P in vivo. MGC803 cells transfected with miR-3664-5P overexpressing lentivirus were injected into nude mice subcutaneously. The tumor size was monitored every 5 days until sacrifice. Compared with the control group, miR-3664-5P overexpression markedly inhibited tumor growth in vivo (Fig. 5A-C), verifying the inhibitory role of miR-3664-5P in the proliferation of GC cells. Consistently, detection of lung metastasis in the nude mice injected through the tail vein with miR-3664-5P overexpressing MGC308 or control cells revealed that an increased expression of miR-3664-5P was significantly associated with reduced lung metastases (Fig. 5D-F).

$M T D H$ is the functional target of miR-3664-5P. Sufficient evidence has demonstrated that miRNAs function by regulating the expression of a target gene (4). To obtain an in-depth understanding of the association between miR-3664-5P 

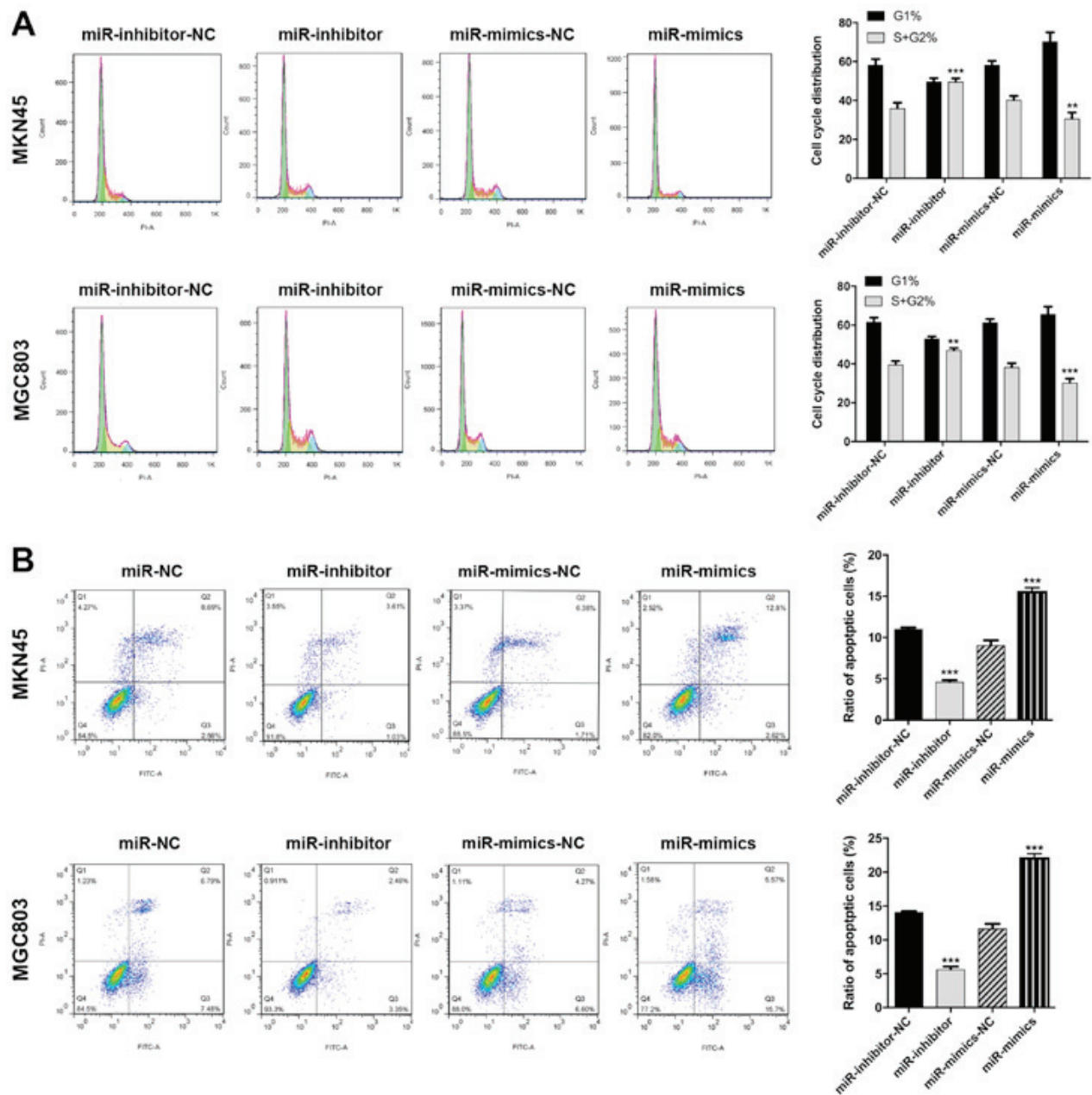

Figure 3. Overexpression of miR-3664-5P increases apoptosis and cell cycle arrest. Following treatment with miR-3664-5P inhibitors and mimics for $48 \mathrm{~h}$, GC cells were stained and analyzed by flow cytometry. (A) The cell cycle distribution of MKN45 and MGC803 cells was detected using flow cytometry and the comparative analysis of cell numbers in the G1 and S + G2 phases are presented. (B) Total apoptosis of MKN45 and MGC803 cells was determined by flow cytometry and the comparative analysis of the number of apoptotic cells is presented. Data are presented as the mean \pm standard error of the mean, from three independent experiments. ${ }^{* *} \mathrm{P}<0.01$ and ${ }^{* * *} \mathrm{P}<0.001$ vs. the corresponding NC. NC, negative control; miR-inhibitor-NC, cells transfected with the negative control of the miR-3664-5P inhibitor; miR-inhibitors, cells transfected with miR-3664-5P inhibitors; miR-mimics-NC, cells transfected with the negative control of the miR-3664-5P mimics; miR-mimics, cells transfected with miR-3664-5P mimics; miR, microRNA; GC, gastric cancer.

and GC, two bioinformatics databases (TargetScan, www. targetscan.org; and miRDB, www.mirdb.org) were utilized to predict the target gene of miR-3664-5P $(29,30)$. The results suggested that MTDH was the candidate with highest potential for binding sites, including 3 conserved putative target sites for miR-3664-5P (70-91, 3,358-3,379 and 5,000-5,021 nt) (data not shown). MTDH mRNA and protein expressions were upregulated in tumor tissues when compared with paired normal tissues (Fig. 6A and B). A Pearson correlation analysis of $100 \mathrm{GC}$ tissues revealed that MTDH expression was negatively correlated with miR-3664-5P expression (Fig. 6C).

For further verification of the interactions between miR-3664-5P and the 3'-UTR of MTDH mRNA, three pairs of WT (pDL-MTDH-30UTR-wt) or Mut (pDL-MTDH-30UTR-mut) reporter vectors were constructed based on the 3 potential binding sites and co-transfected with miR-3664-5P mimics or inhibitors into MGC803 or MKN45 cells, respectively. Among these 3 potential binding sites, the most pronounced decrease in luciferase activity when compared with the WT reporter in MGC803 cells was observed for the second site (3,358-3,379 nt; Fig. 6D and E). MTDH protein expression in MGC803 cells, where miR-3664-5P was knocked down, was further investigated. The results suggested that MTDH expression was decreased in MGC803 cells treated with miR-3664-5P mimics and increased in MKN45 cells treated with miR-3664-5P inhibitors (Fig. 6F). Furthermore, MTDH protein expression was decreased in tumor tissues transfected with miR-3664-5P overexpressing lentivirus in the xenotransplantation model (Fig. 6G). Taken together, these results demonstrated that miR-3664-5P functioned by targeting $\mathrm{MTDH}$

MTDH promotes the antitumor function of miR-3664-5P through the $N F-\kappa B$ signaling pathway. Considering a previous study (23), it was hypothesized that miR-3664-5P may suppress GC by regulating the $\mathrm{NF}-\kappa \mathrm{B}$ signaling pathway, with MTDH as the key protein connecting miR-3664-5P and the $\mathrm{NF}-\kappa \mathrm{B}$ signaling pathway. Rescue assays in MKN45 cells were performed utilizing siRNAs targeting MTDH. CCK8, EdU, plate colony and Transwell assays were performed using MKN45 miR-3664-5P modified cells. The effect of miR-3664-5Pinhibitors on miR-3664-5Pantitumorfunction was 

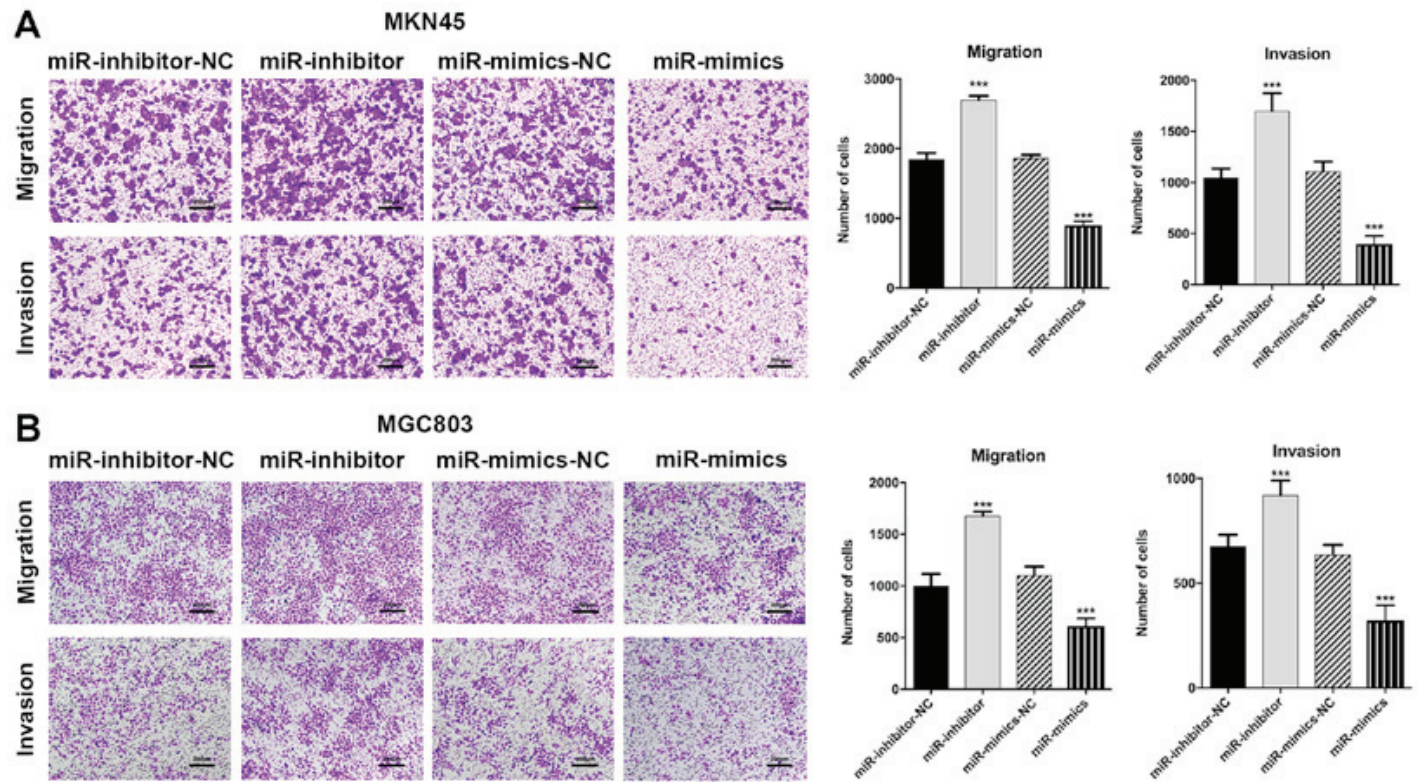

Figure 4. miR-3664-5P inhibits GC cell migration and invasion in vitro. Transwell assays were performed to evaluate the migration and invasion abilities of GC cells. (A and B) The inhibition of miR-3664-5P enhanced, while the overexpression of miR-3664-5P suppressed, the migration and invasion of (A) MKN45 and (B) MGC803 cells. Magnification, x200; scale bars, $200 \mu \mathrm{m}$. Data are presented as the mean \pm standard error of the mean, from three independent experiments. ${ }^{* * *} \mathrm{P}<0.001$ vs. the corresponding NC. NC, negative control; miR-inhibitor-NC, cells transfected with the negative control of the miR-3664-5P inhibitor; miR-inhibitors, cells transfected with miR-3664-5P inhibitors; miR-mimics-NC, cells transfected with the negative control of the miR-3664-5P mimics; miR-mimics, cells transfected with miR-3664-5P mimics; miR, microRNA; GC, gastric cancer.

A
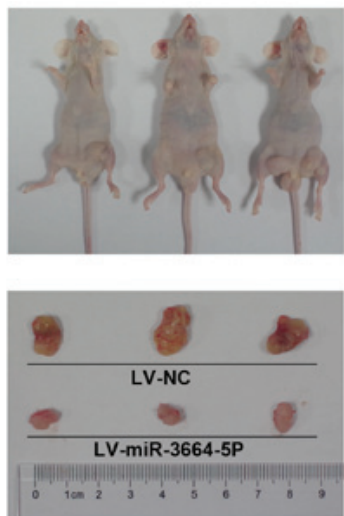

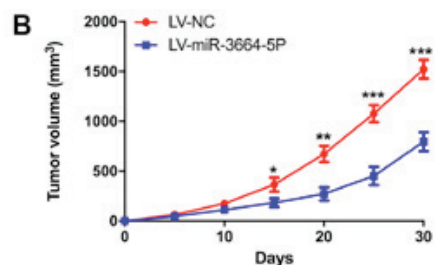

C

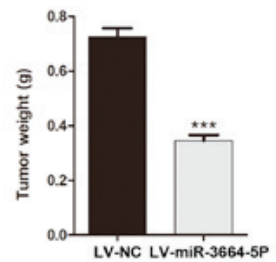

D
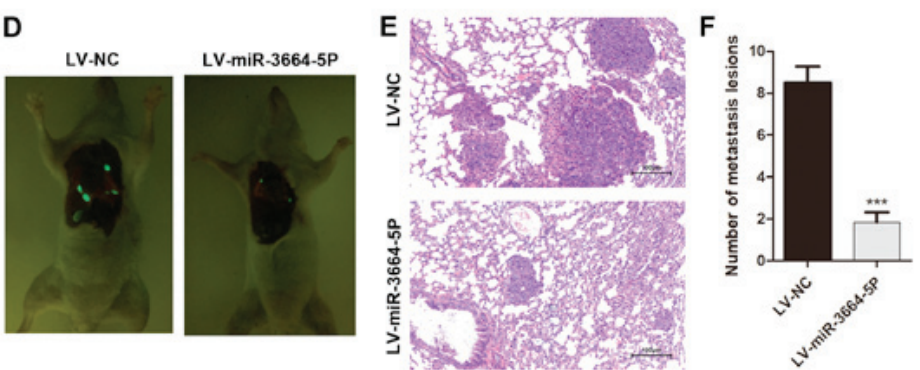

Figure 5. miR-3664-5P inhibits tumor growth in vivo. (A) BALB/c nude mice (age, 6 weeks) were subcutaneously transplanted with LV-miR-3664-5P MGC803 cells $\left(1 \times 10^{7}\right)$ in the left and LV-NC MGC803 cells $\left(1 \times 10^{7}\right)$ in the right groin $(\mathrm{n}=10)$. (B) Tumor volume was determined every 5 days following transplantation and mice were sacrificed following 30 days. Tumor volume was calculated using: (width ${ }^{2} \mathrm{x}$ length)/2. (C) Tumor weight was measured following sacrifice (D) A tail vein xenograft model was constructed to investigate metastasis. (E) Representative images of hematoxylin and eosin staining of tumor tissues from mice subcutaneously injected with miR-3664-5P overexpression cells or NC cells (magnification, x200). (F) The number of metastatic lesions was calculated in each group. Data are presented as the mean \pm standard deviation $(n=10)$. ${ }^{*} \mathrm{P}<0.05,{ }^{* * *} \mathrm{P}<0.01$ and ${ }^{* * *} \mathrm{P}<0.001$ vs. LV-NC. NC, negative control; LV, lentivirus; LV-NC, cells transfected with NC LV; LV-miR-3664-5P, cells transfected with miR-3664-5P overexpression LV; miR, microRNA; GC, gastric cancer.

counteracted by the ectopic expression of MTDH (Fig. 7A-D). Then the expression levels of certain key proteins of the NF- $\mathrm{KB}$ signaling pathway and further downstream targets, including the intercellular adhesion molecule IL-8, MMP9 and VEGF, were assessed. The results revealed a decreased degradation of $\mathrm{I} \kappa \mathrm{B} \alpha$ and an increased phosphorylation of $\mathrm{p} 65$, which induced 
A

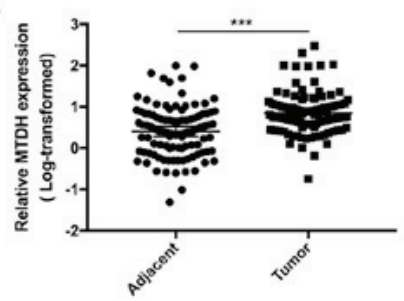

D

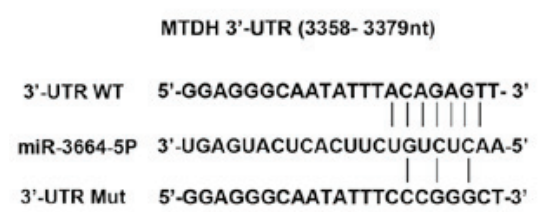

B

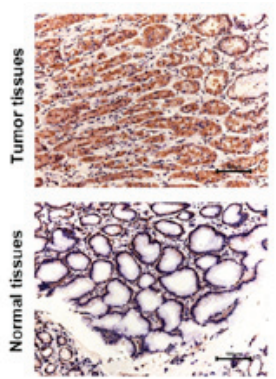

E

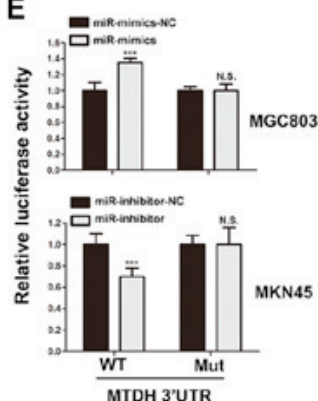

C

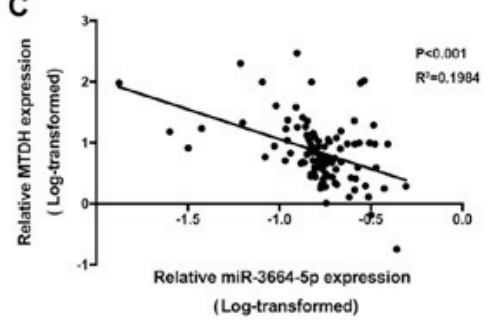

F

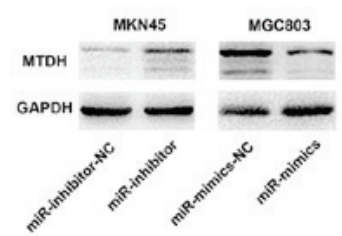

G

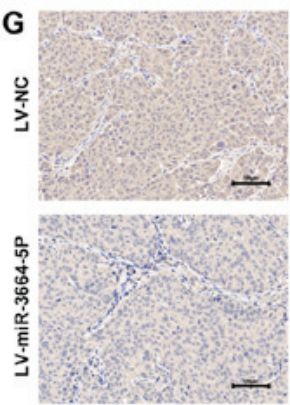

Figure 6. MTDH is the functional target of miR-3664-5P. (A) MTDH levels were significantly increased in GC tissues when compared with the control. ${ }^{* * * *} \mathrm{P}<0.001$, as indicated. (B) IHC was performed to investigate MTDH expression in GC and adjacent normal tissues. Magnification, $\mathrm{x} 200$; scale bars, $100 \mu \mathrm{m}$. (C) Pearson correlation analysis revealed that miR-3664-5P expression was negatively correlated with MTDH expression in GC tissues. (D) miR-3664-5P targeted the 3'-UTR of MTDH and the corresponding mutations of miR-3664-5P were assessed. (E) Luciferase reporter assays were performed to evaluate interactions between miR-3664-5P and candidate genes in GC cell lines. ${ }^{* * *} \mathrm{P}<0.001$ vs. the corresponding NC. (F) MTDH protein levels in GC cells with miR-3664-5P knockdown or overexpression were detected. (G) IHC was performed in the tumor tissues collected from the mouse xenotransplantation model. Magnification, $\mathrm{x} 200$; scale bars, $100 \mu \mathrm{m}$. Data are presented as the mean \pm standard error of the mean. NC, negative control; miR-inhibitor-NC, cells transfected with the negative control of the miR-3664-5P inhibitor; miR-inhibitors, cells transfected with miR-3664-5P inhibitors; miR-mimics-NC, cells transfected with the negative control of the miR-3664-5P mimics; miR-mimics, cells transfected with miR-3664-5P mimics; LV, lentivirus; LV-NC, cells transfected with NC LV; LV-miR-3664-5P, cells transfected with miR-3664-5P overexpression LV; IHC, immunohistochemistry; N.S., not significant; miR, microRNA; GC, gastric cancer; UTR, untranslated region; Mut, mutant; WT, wild-type; MTDH, metadherin.
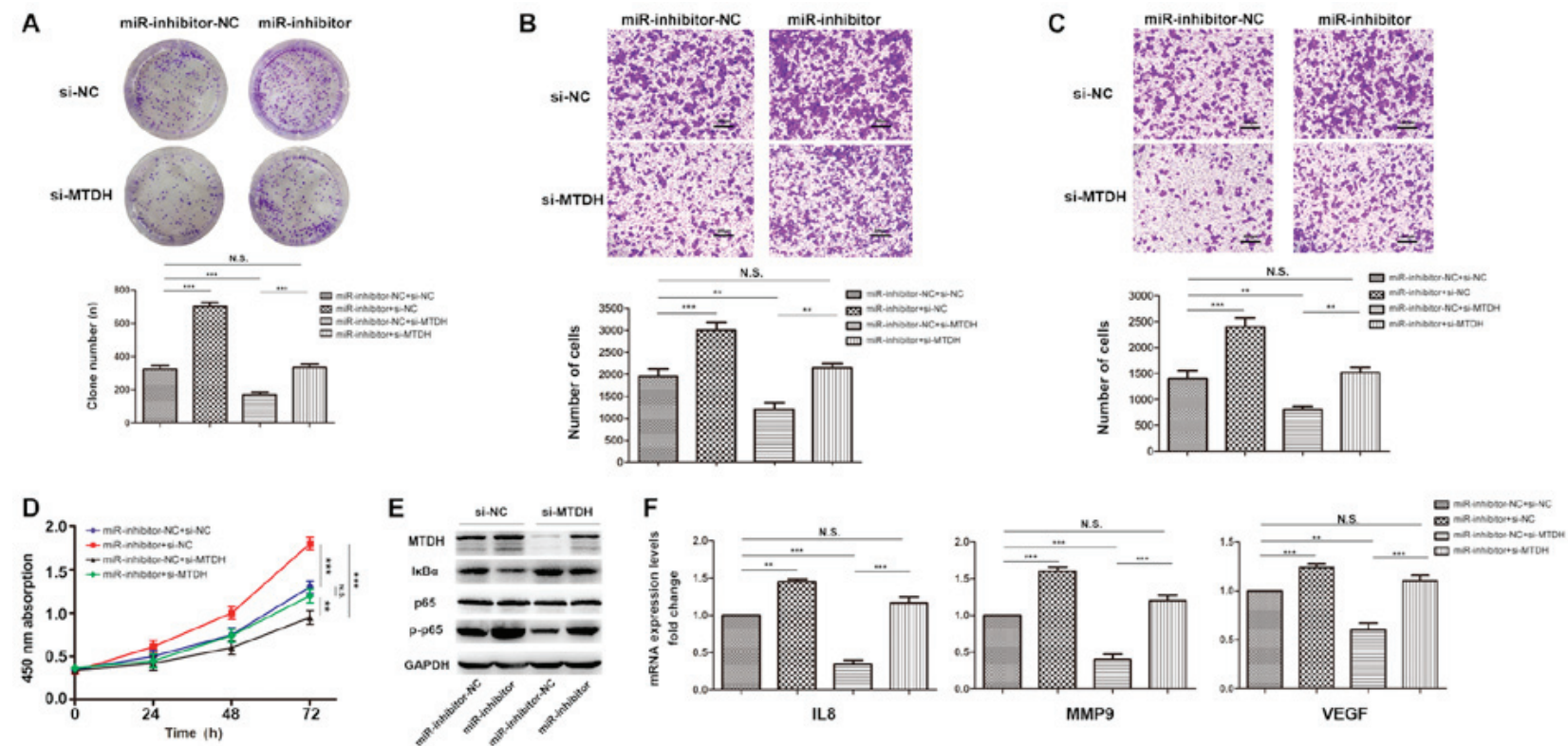

Figure 7. MTDH mediates the antitumor function of miR-3664-5P through the NF- $\kappa B$ signaling pathway. (A-D) miR-3664-5P inhibition enhanced the proliferation, migration and invasion of GC cells as determined by (A) plate colony assays, (B) transwell migration assays, (C) transwell invasion assays and (D) Cell Counting Kit-8 assays, which was reversed following transfection with MTDH siRNA. Magnification, x200; scale bars, $200 \mu \mathrm{m}$. (E) MKN45 transfected with miR-3664-5P inhibitors exhibited significant upregulation of MTDH and key molecules of the NF- $\mathrm{kB}$ signaling. Following transfection with MTDH siRNA, expression levels were restored to the original (untransfected) levels. (F) mRNA expression levels of the downstream targets of the NF- $\mathrm{kB}$ signaling pathway were upregulated in miR-3664-5P inhibited MKN45 cells and this effect was reversed following transfection with MTDH siRNA. Data are presented as the mean \pm standard error of the mean, from three independent experiments. ${ }^{* *} \mathrm{P}<0.01$ and ${ }^{* * *} \mathrm{P}<0.001$, as indicated. NC, negative control; miR-inhibitor-NC, cells transfected with the negative control of the miR-3664-5P inhibitor; miR-inhibitors, cells transfected with miR-3664-5P inhibitors; si-/ siRNA, small interfering RNA; si-NC, siRNA of NC; si-MTDH, siRNA targeting MTDH; N.S., not significant; miR, microRNA; GC, gastric cancer; MTDH,

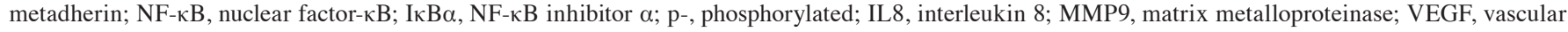
endothelial growth factor. 
the activation of the NF- $\mathrm{BB}$ signaling pathway in miR-3664-5P inhibited MKN45 cells. These observations were reversed to the pre-treatment expression levels following co-transfection with MTDH siRNAs (Fig. 7E). The downstream targets of the $\mathrm{NF}-\kappa \mathrm{B}$ signaling pathway were significantly upregulated in miR-3664-5P inhibited MKN45 cells, and MTDH siRNAs reversed these observations (Fig. 7F). The results indicated that miR-3664-5P suppressed the proliferation of GC cells by regulating $\mathrm{MTDH}$ expression, and the underlying mechanism may be associated with targeting the $\mathrm{NF}-\kappa \mathrm{B}$ signaling pathway.

\section{Discussion}

The tumorigenesis of GC is a complicated process that has not been completely elucidated. Among the associated risk factors, familial inheritance and Helicobacter pylori (H. pylori) infection account for the largest proportion, followed by chronic atrophic gastritis, including pernicious anemia, toxic and dietary agents, previous gastric surgery with bile reflux, hypertrophic gastropathy including Metenier's disease, gastric polyps, low socioeconomic status and obesity (12,31-33). In developing countries particularly, including China, $H$. pylori infection may be the greatest risk factor of GC $(25,32)$. It is widely accepted that $H$. pylori infection promotes the genesis of GC by enhancing the production of free radicals and long-term inflammation of the gastric mucosa $(23,25,32)$. Thus, investigation into the conversion process from the gastric mucosa inflammation to GC will further the understanding of the underlying mechanisms of $\mathrm{GC}$ genesis.

$\mathrm{NF}-\kappa \mathrm{B}$ is a protein complex of transcription factors observed in the $\kappa$-light chain of immunoglobins in B-cells and is composed of five members: Rel (c-Rel), RelA (p65), RelB, NF- $\kappa$ B1 (p50 and its precursor p105) and NF- $\kappa$ B2 (p52 and its precursor p100) $(34,35)$. The classical or canonical $\mathrm{NF}-\kappa \mathrm{B}$ signaling pathway is activated by tumor necrosis factor (TNF), IL-1 and Toll-like receptor ligands, including lipopolysaccharides. Upon stimulation, I $\mathrm{I} \mathrm{B} \alpha$ is phosphorylated and ubiquitinated, triggering the release, translocation and transcription of RelA (P65) (36). Previous studies have demonstrated that the activation of the $\mathrm{NF}-\kappa \mathrm{B}$ signaling pathway is involved in the initiation and progression of a spectrum of different types of gastrointestinal cancers, including liver, pancreatic, prostate and lung cancers (37-42). In GC, chronic inflammation, including that induced by $H$. pylori infection, greatly increases the risk of cancer via a process that involves the production of protumorigenic cytokines, including TNF, IL-1, IL-6, IL-17A and IL-23, promoting the activation of the $\mathrm{NF}-\kappa \mathrm{B}$ and signal transducer and activator of transcription 3 signaling pathways (43). NF- $\kappa \mathrm{B}$ acts in epithelial and myeloid cells, and mainly suppresses cell death and sustains cell survival in epithelial cells, consequently aggravating disease progression (34). MTDH, a classical oncoprotein, was reported to be involved in the activation of the NF- $\mathrm{B}$ signaling pathway (23). Upon the engagement of the upstream cytokines to receptors, MTDH will be phosphorylated by $\mathrm{I} \kappa \mathrm{B}$ kinase $\beta$, then interact with P65, which finally promotes the translocation and transcriptional activity of P65 $(44,45)$. In the present study, the significant role of miR-3664-5P in the suppression of the NF- $\mathrm{B}$ signaling pathway was highlighted by targeting MTDH and inhibiting the proliferation and metastasis of GC, which was validated in vitro and in vivo. Analysis of the association between miR-3664-5P and the clinical data from patients with GC revealed that miR-3664-5P was significantly associated with the clinical features of GC tumor differentiation and tumor size, and positively correlated with the outcome of patients with GC. It should be noted that the present results do not agree with previously established data, in which GC prognosis was determined by the invasion of layers in the gastric mucosa ( $\mathrm{T}$ classification) and lymph node metastasis $(46,47)$, these were also not significantly associated with the expression of miR-3664-5P in the present cohort. Considering that correlation and prognostic analyses can provide supporting evidence to the conclusions in vitro and in vivo, and the results are cohort- and cohort capacity-dependent, it should be further investigated in a large cohort to confirm the results of the present study. Notably, the potential of miR-3664-5P to serve as a diagnosis marker in patient serum was also uncovered and verified in present study.

In conclusion, the present study suggested that during the tumorigenesis and progression of GC, miR-3664-5P suppressed the proliferation and metastasis of GC by attenuating the $\mathrm{NF}-\kappa \mathrm{B}$ signaling pathway through targeting MTDH. This highlights the potential of miR-3664-5P of being a prognostic and diagnostic indicator in GC.

\section{Acknowledgements}

The authors would like to thank Dr Hao Han (The First Affiliated Hospital of Nanjing Medical University, Jiangsu, China) for providing language and technological support.

\section{Funding}

The present study was supported in part by the National Natural Science Foundation of China (grant no. 81700537).

\section{Availability of data and materials}

The datasets used and/or analyzed during the current study are available from the corresponding author on reasonable request.

\section{Authors' contributions}

LT conceived and designed the study. YJ, HY and JQ acquired the data, and performed the experiments and statistical analysis. YG and HL carried out the patient follow-up procedures. SW and LC analyzed and interpreted the data. YJ and LT drafted and edited the manuscript. All authors have given final approval of the version to be published.

\section{Ethics approval and consent to participate}

The present study was approved by the Ethics Committee of the Nanjing Medical University Affiliated Changzhou No. 2 People's Hospital (approval no. 2010-SR-077.A1; Jiangsu, China) and all patients provided written informed consent. All experiments were approved by Animal Ethics Committee of Nanjing Medical University (Jiangsu, China). 


\section{Patient consent for publication}

The present study obtained consent for publication from all patients.

\section{Competing interests}

The authors declare that they have no competing interests.

\section{References}

1. Torre LA, Bray F, Siegel RL, Ferlay J, Lortet-Tieulent J and Jemal A: Global cancer statistics, 2012. CA Cancer J Clin 65 87-108, 2015

2. Jemal A, Bray F, Center MM, Ferlay J, Ward E and Forman D: Global cancer statistics. CA Cancer J Clin 61: 69-90, 2011.

3. Ferlay J, Steliarova-Foucher E, Lortet-Tieulent J, Rosso S, Coebergh JW, Comber H, Forman D and Bray F: Cancer incidence and mortality patterns in Europe: estimates for 40 countries in 2012. Eur J Cancer 49: 1374-1403, 2013.

4. Bartel DP: MicroRNAs: Genomics, biogenesis, mechanism, and function. Cell 116: 281-297, 2004.

5. Peng Y, Zhang X, Ma Q, Yan R, Qin Y, Zhao Y, Cheng Y, Yang M, Wang Q, Feng X, et al: MiRNA-194 activates the Wnt/ $\beta$-catenin signaling pathway in gastric cancer by targeting the negative Wnt regulator, SUFU. Cancer Lett 385: 117-127, 2017.

6. Luo $\mathrm{H}$ and Liang C: MicroRNA-148b inhibits proliferation and the epithelial-mesenchymal transition and increases radiosensitivity in non-small cell lung carcinomas by regulating ROCK1. Exp Ther Med 15: 3609-3616, 2018.

7. Gruszka R and Zakrzewska M: The oncogenic relevance of miR-17-92 cluster and its paralogous miR-106b-25 and miR-106a-363 clusters in brain tumors. Int J Mol Sci 19: 19, 2018.

8. Inoue A, Mizushima T, Wu X, Okuzaki D, Kambara N Ishikawa S, Wang J, Qian Y, Hirose H, Yokoyama Y, et al: A miR-29b Byproduct Sequence Exhibits Potent Tumor-Suppressive Activities via Inhibition of NF- $\kappa$ B Signaling in KRAS-Mutant Colon Cancer Cells. Mol Cancer Ther 17: 977-987, 2018.

9. Garzon R, Marcucci G and Croce CM: Targeting microRNAs in cancer: Rationale, strategies and challenges. Nat Rev Drug Discov 9: 775-789, 2010.

10. Murray-Stewart T, Sierra JC, Piazuelo MB, Mera RM Chaturvedi R, Bravo LE, Correa P, Schneider BG, Wilson KT and Casero RA: Epigenetic silencing of miR-124 prevents spermine oxidase regulation: Implications for Helicobacter pylori-induced gastric cancer. Oncogene 35: 5480-5488, 2016.

11. Cao Y, Tan S, Tu Y, Zhang G, Liu Y, Li D, Xu S, Le Z, Xiong J, Zou W, et al: MicroRNA-125a-5p inhibits invasion and metastasis of gastric cancer cells by targeting BRMS1 expression. Oncol Lett 15: 5119-5130, 2018.

12. Yu X, Ma C, Fu L, Dong J and Ying J: MicroRNA-139 inhibits the proliferation, migration and invasion of gastric cancer cells by directly targeting @-associated protein kinase 1 . Oncol Lett 15: 5977-5982, 2018.

13. Hu L, Wu H, Wan X, Liu L, He Y, Zhu L, Liu S, Yao H and Zhu Z MicroRNA-585 suppresses tumor proliferation and migration in gastric cancer by directly targeting MAPK1. Biochem Biophys Res Commun 499: 52-58, 2018

14. Yan C, Yu J, Liu Y, Kang W, Ma Z and Zhou L: MiR-32 promotes gastric carcinoma tumorigenesis by targeting Kruppel-like factor 4. Biochem Biophys Res Commun 467: 913-920, 2015.

15. Delaunoit T: Latest developments and emerging treatment options in the management of stomach cancer. Cancer Manag Res 3: 257-266, 2011.

16. Su ZZ, Kang DC, Chen Y, Pekarskaya O, Chao W, Volsky DJ and Fisher PB: Identification and cloning of human astrocyte genes displaying elevated expression after infection with HIV-1 or exposure to HIV-1 envelope glycoprotein by rapid subtraction hybridization, RaSH. Oncogene 21: 3592-3602, 2002.

17. Lee SG, Kim K, Kegelman TP, Dash R, Das SK, Choi JK, Emdad L, Howlett EL, Jeon HY, Su ZZ, et al: Oncogene AEG-1 promotes glioma-induced neurodegeneration by increasing glutamate excitotoxicity. Cancer Res 71: 6514-6523, 2011

18. Park SY, Choi M, Park D, Jeong M, Ahn KS, Lee J, Fisher PB, Yun $M$ and Lee SG: AEG-1 promotes mesenchymal transition through the activation of Rho GTPases in human glioblastoma cells. Oncol Rep 36: 2641-2646, 2016.
19. Liang Y, Hu J, Li J, Liu Y, Yu J, Zhuang X, Mu L, Kong X, Hong D, Yang Q, et al: Epigenetic Activation of TWIST1 by MTDH Promotes Cancer Stem-like Cell Traits in Breast Cancer. Cancer Res 75: 3672-3680, 2015

20. Hu G, Chong RA, Yang Q, Wei Y, Blanco MA, Li F, Reiss M, Au JL, Haffty BG and Kang Y: MTDH activation by $8 \mathrm{q} 22$ genomic gain promotes chemoresistance and metastasis of poor-prognosis breast cancer. Cancer Cell 15: 9-20, 2009.

21. Robertson CL, Srivastava J, Siddiq A, Gredler R, Emdad L, Rajasekaran D, Akiel M, Shen XN, Guo C, Giashuddin S, et al: Genetic deletion of AEG-1 prevents hepatocarcinogenesis. Cancer Res 74: 6184-6193, 2014.

22. Srivastava J, Siddiq A, Emdad L, Santhekadur PK, Chen D, Gredler R, Shen XN, Robertson CL, Dumur CI, Hylemon PB, et al: Astrocyte elevated gene-1 promotes hepatocarcinogenesis: Novel insights from a mouse model. Hepatology 56: 1782-1791, 2012.

23. Li G, Wang Z, Ye J, Zhang X, Wu H, Peng J, Song W, Chen C, Cai S, He Y, et al: Uncontrolled inflammation induced by AEG-1 promotes gastric cancer and poor prognosis. Cancer Res 74: 5541-5552, 2014.

24. Liu H, Song X, Liu C, Xie L, Wei L and Sun R: Knockdown of astrocyte elevated gene-1 inhibits proliferation and enhancing chemo-sensitivity to cisplatin or doxorubicin in neuroblastoma cells. J Exp Clin Cancer Res 28: 19, 2009.

25. Dicken BJ, Bigam DL, Cass C, Mackey JR, Joy AA and Hamilton SM: Gastric adenocarcinoma: Review and considerations for future directions. Ann Surg 241: 27-39, 2005.

26. Ikoma N, Blum M, Estrella JS, Das P, Hofstetter WL, Fournier KF, Mansfield P, Ajani JA and Badgwell BD: Evaluation of the American Joint Committee on Cancer 8th edition staging system for gastric cancer patients after preoperative therapy. Gastric Cancer 21: 74-83, 2018.

27. Livak KJ and Schmittgen TD: Analysis of relative gene expression data using real-time quantitative PCR and the 2(-Delta Delta C(T)) method. Methods 25: 402-408, 2001.

28. Lewis BP, Burge CB and Bartel DP: Conserved seed pairing, often flanked by adenosines, indicates that thousands of human genes are microRNA targets. Cell 120: 15-20, 2005.

29. Wong $N$ and Wang X: miRDB: An online resource for microRNA target prediction and functional annotations. Nucleic Acids Res 43 (D1): D146-D152, 2015.

30. Agarwal V, Bell GW, Nam JW and Bartel DP: Predicting effective microRNA target sites in mammalian mRNAs. eLife 4: 4, 2015.

31. Hu Y, Yu K, Wang G, Zhang D, Shi C, Ding Y, Hong D, Zhang D, $\mathrm{He} \mathrm{H}$, Sun L, et al: Lanatoside $\mathrm{C}$ inhibits cell proliferation and induces apoptosis through attenuating $\mathrm{Wnt} / \beta$-catenin/c-Myc signaling pathway in human gastric cancer cell. Biochem Pharmacol 150: 280-292, 2018

32. Wang F, Meng W, Wang B and Qiao L: Helicobacter pylori-induced gastric inflammation and gastric cancer. Cancer Lett 345: 196-202, 2014.

33. Van Cutsem E, Dicato M, Geva R, Arber N, Bang Y, Benson A, Cervantes A, Diaz-Rubio E, Ducreux M, Glynne-Jones R, et al: The diagnosis and management of gastric cancer: expert discussion and recommendations from the 12th ESMO/World Congress on Gastrointestinal Cancer, Barcelona, 2010. Ann Oncol 22 (Suppl 5): v1-v9, 2011.

34. He G and Karin M: NF- $\mathrm{BB}$ and STAT3 - key players in liver inflammation and cancer. Cell Res 21: 159-168, 2011.

35. Ghosh S and Karin M: Missing pieces in the NF-kappaB puzzle. Cell 109 (Suppl): S81-S96, 2002.

36. Zandi E, Rothwarf DM, Delhase M, Hayakawa M and Karin M: The IkappaB kinase complex (IKK) contains two kinase subunits, IKKalpha and IKKbeta, necessary for IkappaB phosphorylation and NF-kappaB activation. Cell 91: 243-252, 1997.

37. Grivennikov S, Karin E, Terzic J, Mucida D, Yu GY, Vallabhapurapu S, Scheller J, Rose-John S, Cheroutre H, Eckmann L, et al: IL-6 and Stat3 are required for survival of intestinal epithelial cells and development of colitis-associated cancer. Cancer Cell 15: 103-113, 2009.

38. Pikarsky E, Porat RM, Stein I, Abramovitch R, Amit S, Kasem S, Gutkovich-Pyest E, Urieli-Shoval S, Galun E and Ben-Neriah Y: NF-kappaB functions as a tumour promoter in inflammation-associated cancer. Nature 431: 461-466, 2004.

39. He G, Yu GY, Temkin V, Ogata H, Kuntzen C, Sakurai T, Sieghart W, Peck-Radosavljevic M, Leffert HL and Karin M: Hepatocyte IKKbeta/NF-kappaB inhibits tumor promotion and progression by preventing oxidative stress-driven STAT3 activation. Cancer Cell 17: 286-297, 2010. 
40. Jin R, Yi Y, Yull FE, Blackwell TS, Clark PE, Koyama T, Smith JA Jr and Matusik RJ: NF- $\kappa \mathrm{B}$ gene signature predicts prostate cancer progression. Cancer Res 74: 2763-2772, 2014.

41. Todoric J, Antonucci L, Di Caro G, Li N, Wu X, Lytle NK, Dhar D, Banerjee S, Fagman JB, Browne CD, et al: Stress-Activated NRF2-MDM2 Cascade Controls Neoplastic Progression in Pancreas. Cancer Cell 32: 824-839.e8, 2017.

42. Chen W, Li Z, Bai L and Lin Y: NF-kappaB in lung cancer, a carcinogenesis mediator and a prevention and therapy target. Front Biosci 16: 1172-1185, 2011.

43. Karin M: NF-kappaB as a critical link between inflammation and cancer. Cold Spring Harb Perspect Biol 1: a000141, 2009.

44. Krishnan RK, Nolte H, Sun T, Kaur H, Sreenivasan K, Looso M, Offermanns S, Krüger M and Swiercz JM: Quantitative analysis of the TNF- $\alpha$-induced phosphoproteome reveals AEG-1/MTDH/LYRIC as an IKK $\beta$ substrate. Nat Commun 6: 6658,2015 .
45. Emdad L, Sarkar D, Su ZZ, Randolph A, Boukerche H, Valerie K and Fisher PB: Activation of the nuclear factor kappaB pathway by astrocyte elevated gene-1: Implications for tumor progression and metastasis. Cancer Res 66: 1509-1516, 2006.

46. Jiao X, Lu HJ, Zhai MM, Tan ZJ, Zhi HN, Liu XM, Liu CH and Zhang DP: Overexpression of kallikrein gene 10 is a biomarker for predicting poor prognosis in gastric cancer. World J Gastroenterol 19: 9425-9431, 2013.

47. Deng JY and Liang H: Clinical significance of lymph node metastasis in gastric cancer. World J Gastroenterol 20: 3967-3975, 2014.

(i) $\ominus$ This work is licensed under a Creative Commons Attribution-NonCommercial-NoDerivatives 4.0 International (CC BY-NC-ND 4.0) License. 